\title{
Tarim transitional large igneous province (LIP): Insight into the correlation between mafic and silicic \\ LIPs
}

\author{
ZHAOCHONG ZHANG ${ }^{1 *}$, ZHIGUO CHENG ${ }^{1}$, \\ WEILIANG KONG ${ }^{1}$, BINGXIANG LIU ${ }^{1}$, ZHENCHAO \\ WANG $^{1}$, BOWEN WEI ${ }^{1}$ \\ ${ }^{1}$ State Key Laboratory of Geological Processes and Mineral \\ Resources, China University of Geosciences, Beijing 100083, \\ China (Correspondence: zczhang@,cugb.edu.cn)
}

In terms of the proportion of felsic rocks, large igneous provinces (LIPs) have been divided into mafic and silicic LIPs. Compared to Silicic LIPs that are dominated by felsic rocks with minor basalt, the mafic LIPs contain much less felsic rocks, generally $<10 \%$. The remarkably different mafic and silicic LIPs were suggested to represent two end members in the LIP clan, whereas transitional LIPs with similar proportion of mafic and felsic rocks were largely missing in the geological record. The Tarim Early Permian LIP is located in the Tarim Craton in the northwestern part of China. It covers a large area of felsic volcanic rocks $(\sim 48,000$ $\mathrm{km}^{2}$ ) and approximately $265,000 \mathrm{~km}^{2}$ of basalts. The high proportion of the felsic rocks classifies the TLIP as a transitional LIP, which is distinct from the typical mafic LIPs.

The Tarim LIP contains almost all the lithology in global LIPs. Our studies have identified the sequence of formation of these rocks as: ca. 300 Ma aillikitic pipes $\rightarrow$ ca. $290 \mathrm{Ma}$ flood basalts and felsic lavas $\rightarrow$ ca. 280 Ma mafic-ultramafic intrusions, carbonatite and alkaline dykes $\rightarrow 270 \mathrm{Ma}$ nephelinite. Most of the igneous rocks in the Tarim LIP are characterized by sodium- and iron-rich affinities, and the felsic rocks contain some phenocrysts of hydrous mafic minerals. The mineralogical, petrological, elemental and $\mathrm{Sr}$ $\mathrm{Nd}-\mathrm{Mg}-\mathrm{Zn}-\mathrm{O}-\mathrm{C}$ isotopic characteristics suggest three domains for the sources of Tarim LIPs. One is lithospheric mantle with the 'iron-rich streaks' that have been resulted from recycled oceanic crusts for basalts and mafic-ultramafic intrusions. The second one is upwelling plume entraining subducted slabs with magnesite, periclase and perovskite that are recycled sedimentary carbonates for carbonatite, nephelinite and aillikitic rocks. The third one is hydrous crust for the felsic rocks. Thus, the iron-rich features of the TLIP can be attributed to dense eclogite (recycled oceanic crust), and the sodic affinity of some alkaline rocks are ascribed to recycled carbonates. The complex lithology is correlated to be resulted from partial melting of different sources or different melting degrees of the same source, whilst hydrous crustal components provided significant input in producing the voluminous felsic rocks of the Tarim LIP. 